\title{
Usage of the relationship between the application rates of the active ingredient of fungicides and their residue levels in mature apples to creating a coherent system of MRLs
}

\author{
Stanisław Sadło ${ }^{1} \cdot$ Stanisław Walorczyk $^{2} \cdot$ Przemysław Grodzicki $^{3} \cdot$ \\ Bartosz Piechowicz ${ }^{1}$
}

Received: 12 October 2015/ Accepted: 18 April 2016/Published online: 9 May 2016

(c) The Author(s) 2016. This article is published with open access at Springerlink.com

\begin{abstract}
Setting of maximum residue levels (MRLs; tolerances in the USA) in crops requires a big amount of data concerning residues from a number of supervised field trials for each pesticide/crop combination. This task is time-consuming, costly and fairly complicated. Therefore, we initiated a study on the utilization of the interpolation method in supporting and facilitating of assessing the value of the MRLs which are now being in use, and in creating their consistent system in the future. A mathematical formula for predicting the initial pesticide residue level in mature apples was developed by establishing the relationship between application rates and residue levels of the pesticide active ingredients in mature apples. This dependence was described by a linear equation $R_{0}=1.2593 \times D$, with coefficient of determination $r^{2}=0.984$, where $D$ is an application rate of a given substance. This relationship makes it possible to predict a residue level of other substances of fungicidal activity. Thus, residue levels (both predicted by the formula and obtained in the frame of Polish National Monitoring Program) of fungicides now used in apple orchards, in mature apples were typically lower than those of the statutory MRLs. Bearing in mind that the European Union policy is directed towards substantial reduction in pesticide use, the
\end{abstract}

Bartosz Piechowicz

bpiechow@poczta.onet.pl

1 Institute of Applied Biotechnology and Basic Sciences, University of Rzeszów, Werynia 502, 36-100 Kolbuszowa, Poland

2 Department of Pesticide Residue Research, Institute of Plant Protection - National Research Institute, Władysława Węgorka 20, 60-318 Poznań, Poland

3 Department of Animal Physiology, Faculty of Biology and Environment Protection, Nicolaus Copernicus University, Lwowska 1, 87-100 Toruń, Poland
MRLs might be reconsidered in order to be set at lower values.

Keywords Application rate - Mature apples - Maximum residue levels $\cdot$ Pesticide residues

\section{Introduction}

Among the food safety hazards for the consumers, pesticide residues, some bacterial pathogens (e.g. Salmonella enterica) and foodborne viruses (e.g. norovirus) have been identified as three most important risk factors [4]. In order to safeguard consumers' health and to promote principles of good agricultural practice (GAP) in the use of pesticides, maximum residue levels (MRLs; tolerances in the USA) of pesticides have been set by all EU Member States applying the same evaluation procedures and authorization criteria in order to put a plant protection product (PPP) on the market. These MRLs represent the highest concentrations of pesticides (expressed in $\mathrm{mg}$ of active ingredient per $\mathrm{kg}$ ) which are legally permitted in food commodities, and they are interpreted as the highest residue of a given substance which may be found if a pesticide, registered and authorized, is applied according to label and, therefore, also to principles of GAP [8]. So defined MRLs can be established only when the residues in a crop resulting from particular use pattern of the pesticide meet the public health risk assessment criteria [8, 14, 19]. Despite international discrepancies between food safety regulations, compliance with MRLs is still an essential prerequisite in trade of food and agricultural products [6, 23, 24].

The residue levels of pesticides occurring in crops at harvest time are dependent on many factors and are susceptible to influence of parameters such as a spray 
equipment used, a spray quality and conditions, crop management, crop varieties, practices of growing, growth stages at time of application and weather conditions [8]. But the most important determining factors are application rate of the active ingredient (AI) per hectare and an interval between the last application and the harvest (pre-harvest interval PHI). It appears fairly obvious that relatively high residues may be expected when pesticides are applied at high doses later in growing season when plant growth rate is slow [17].

For setting MRLs, residue data obtained from a number of supervised field trials are required for each pesticide/ crop combination. This task is time-consuming, costly and fairly complicated to perform $[2,3,8,16]$. However, development of a consistent approach for supporting and facilitating estimation of the MRLs based on effective application rate (dose) of the AI appears to be feasible. For this reason, we initiated the field trials to investigate whether the interpolation method may be efficient in predicting of the residue levels of fungicides now used in apple orchards against diseases that potentially may develop during fruit storage. Apples are particularly interesting study object, since these fruits are heavily exposed to pesticide contamination due to numerous pesticide treatments to whom they are subjected, and because they are the most highly consumed fruits (along with oranges) in the European Union countries and the USA.

\section{Materials and methods}

\section{Field trials}

The field trials were carried out in a commercial orchard which was located near the Kraśnik town (Lublin Province, south-eastern Poland) in 2011-2012. The orchard is specialized in providing apples for baby food production and was certified in compliance with Integrated Pest Management (IPM) system by the Main Inspectorate of Plant Health and Seed Inspection (PIORiN-Państwowa Inspekcja Ochrony Roślin i Nasiennictwa).

Trial 1: To protect apples against fungal diseases that develop during the cold storage, apple trees of Gloster variety were sprayed with Switch $62.5 \mathrm{WG}$, a commercial product containing $375 \mathrm{~g} \mathrm{~kg}^{-1}$ of cyprodinil and $250 \mathrm{~g} \mathrm{~kg}^{-1}$ of fludioxonil in the form of water dispersible granules (WG), at a dose of $0.8 \mathrm{~kg} \mathrm{ha}^{-1}$. Switch $62.5 \mathrm{WG}$, which is a mixture of compounds belonging to anilinopyrimidine and phenylpyrrole chemical groups, exhibits a protective and systemic activity against infections of fruits and vegetables by Botrytis cinerea (grey mould).

Trial 2: One week before harvesting mature apples, and submitting them to the storage room, apple trees of Lobo variety were sprayed with Zato $50 \mathrm{WG}$, at a dose of $0.2 \mathrm{~kg} \mathrm{ha}^{-1}$. Trifloxystrobin, the AI of this plant protection product, belongs to the family of strobilurin fungicides and exhibits systemic mode of action.

Trials 3 and 4: These two field trials were carried out on the apple trees of Gloster and Lobo varieties, which were sprayed with fungicides Merpan 80 WG and Captan 80 WG (in both cases, the active ingredient was captan) at a dose of $1.9 \mathrm{~kg} \mathrm{ha}^{-1}$. According to the label, Merpan 80 WG or 50 WP is recommended to control apple scab (Venturia inaequalis). Preparations containing captan (and folpet belonging to the same phthalimide group) are the fungicides commonly used to control the mentioned disease during the whole vegetative period.

Trial 5: Apple trees of Golden Delicious variety were sprayed with the Bellis 38 WG $(25.5 \%$ boscalid and $12 \%$ pyraclostrobin) using $0.8 \mathrm{~kg}$ of the fungicide per ha. Bellis $38 \mathrm{WG}$ is composed of two AIs: pyraclostrobin belonging to strobilurin group, and boscalid, preventive fungicide with curative action belonging to the anilide chemical group.

Trial 6: Similarly to the field trial 2, apple trees of Gloster variety were sprayed with Zato $50 \mathrm{WG}$, but at a lower dose of $0.15 \mathrm{~kg} \mathrm{ha}^{-1}$.

\section{Sampling}

Each time, sampling was made at the next day after pesticide application (approximately after $12 \mathrm{~h}$ ). Each laboratory sample consisted of eight apples collected from randomly selected trees. Of each field trial, four laboratory samples were taken, each of them from one randomly selected row of the apple trees. Fruit samples were transported to the laboratory where they were homogenized, and then analytical portions of known weight (each of them weighing about a hundred grams) were used for the pesticide residue analysis.

\section{Pesticide residue analysis}

Reagents and standards: acetone and dichloromethane of HPLC grade were obtained from Sigma-Aldrich Sp. z o.o., Poznań, Poland. Petroleum ether (Chempur, Piekary Śląskie, Poland) and diethyl ether (POCH, Gliwice, Poland) were distilled from glass before use. Sodium sulphate(VI) (POCH, Gliwice, Poland) was heated at $550{ }^{\circ} \mathrm{C}$ for $7 \mathrm{~h}$. Florisil (Sigma-Aldrich Sp. z o.o., Poznań, Poland) was activated by heating at $130-135{ }^{\circ} \mathrm{C}$ for $7 \mathrm{~h}$ and stored in a desiccator before use. Certified pesticide analytical standards were obtained from Ehrenstorfer (Augsburg, Germany). Stock solutions of approximately $1000 \mu \mathrm{g} \mathrm{mL}{ }^{-1}$ were prepared in acetone and stored at $-17^{\circ} \mathrm{C}$ of which intermediate concentration standards $\left(10 \mu \mathrm{g} \mathrm{mL}^{-1}\right)$ were 
prepared by dilution with acetone (stored at $4{ }^{\circ} \mathrm{C}$ ). Working standard mixtures were obtained by diluting the intermediate concentration solutions with appropriate volumes of petroleum ether and stored at $4{ }^{\circ} \mathrm{C}$.

Sample preparation: the sample preparation was carried out according to the analytical method which was previously described in detail $[18,21]$. Briefly, an analytical portion (about $100 \mathrm{~g}$ ) was homogenized for $2 \mathrm{~min}$ with $150 \mathrm{~mL}$ of acetone. The extract was filtered, and then an aliquot of the filtrate (equivalent to $20 \mathrm{~g}$ of the analytical portion) was taken for further processing. After addition of $100 \mathrm{~mL}$ of $2.5 \%$ aqueous solution of sodium sulphate(VI), it was partitioned sequentially liquid-liquid with 20,10 and $10 \mathrm{~mL}$ dichloromethane. The combined extracts were evaporated to dryness and dissolved with $10 \mathrm{~mL}$ petroleum ether. An aliquot of $5 \mathrm{~mL}$ was transferred into a glass column which was previously packed with $1.1 \mathrm{~g}$ activated florisil and $4.5 \mathrm{~g}$ anhydrous sodium sulphate(VI). The residues were eluted with $70 \mathrm{~mL}$ diethyl ether/petroleum ether $(3: 7, v / v)$ and $70 \mathrm{~mL}$ acetone/petroleum ether (3:7, $v /$ $v)$. The combined extracts were evaporated and diluted with petroleum ether. The concentration of matrix in the final extract was $1 \mathrm{~g}$ per $\mathrm{mL}$.

Gas chromatographic determination: a gas chromatograph model 7890 (Agilent Technologies, Palo Alto, CA, USA) was used. The instrument was equipped with a micro-electron capture $(\mu \mathrm{EC})$ and nitrogen-phosphorus (NP) detectors. The HP-5 MS Ultra Inert capillary column $30 \mathrm{~m} \times 0.32 \mathrm{~mm} \times 0.25 \mu \mathrm{m}$ film thickness (Agilent Technologies, Palo Alto, CA, USA) was used. Sample extracts of $2 \mu \mathrm{l}$ were injected splitless at $250{ }^{\circ} \mathrm{C}$. The column temperature was ramped from 100 to $180{ }^{\circ} \mathrm{C}$ at $10{ }^{\circ} \mathrm{C} \mathrm{min}-1$ (held for $4 \mathrm{~min}$ ), then ramped to $220^{\circ} \mathrm{C}$ at $3{ }^{\circ} \mathrm{C} \min ^{-1}$ (held for $15 \mathrm{~min}$ ), then ramped to $260{ }^{\circ} \mathrm{C}$ at $10{ }^{\circ} \mathrm{C} \mathrm{min}{ }^{-1}$ (held for $11 \mathrm{~min}$ ). Cyprodinil and fludioxonil were determined by using the nitrogen-phosphorus detector (NPD) which was operated at $300{ }^{\circ} \mathrm{C}$ while the gas flows were as follows: hydrogen $3 \mathrm{~mL} \mathrm{~min}{ }^{-1}$, air $60 \mathrm{~mL} \mathrm{~min}^{-1}$ and makeup (nitrogen) $10 \mathrm{~mL} \mathrm{~min}{ }^{-1}$. Boscalid, captan, piraclostrobin and trifloxystrobin were determined by using the micro-electron capture detector $(\mu \mathrm{ECD})$ which was operated at $280{ }^{\circ} \mathrm{C}$, and the makeup gas flow (nitrogen) was $30 \mathrm{~mL} \mathrm{~min}^{-1}$. Agilent Technologies ChemStation Rev.B04.03 software was used for instrument control, data acquisition and evaluation.

\section{Pesticide residue estimation}

Residues of the tested substances were determined by gas chromatographic analysis, and their values were expressed in $\mathrm{mg}$ of AI per $\mathrm{kg}$ of apples. Average residue levels $(n=4)$, standard deviations and coefficients of variations (CV)/relative standard deviations (RSDs) of the obtained values were calculated. Subsequently, the relationship between the two variables: average residue level $(y)$ and application rate $(x)$ of the tested substances was established in the form of linear equation of $y=a x$, based on the assumption that this relationship is linear, and the straight line goes through the point $(0,0)$ on graph $(y$-intercept $=0)$.

\section{Results and discussion}

\section{Method validation study}

To ensure quality of the analytical results, the method was validated before the use to determine the fungicide residues in the apple samples (Table 1). The recovery of the fungicides was determined for samples of untreated apples which were spiked with the target compounds on two concentration levels $(n=5)$. The average recoveries were satisfactory because they were compliant with the European Union criteria (SANCO/12495/2011) which stipulate the average recoveries in the range $70-120 \%$ with corresponding RSD less or equal $20 \%$ (http://ec.europa.eu/food/plant/plant_ protection_products/guidance_documents/docs/qualcontrol_ en.pdf).

The limit of quantification (LOQ) was defined as the lowest spiking level (rounded to one significant number) for which the validation criteria were satisfied and it was equal $0.01 \mathrm{mg} \mathrm{kg}^{-1}$ for boscalid, captan, cyprodinil, piraclostrobin and trifloxystrobin, and $0.02 \mathrm{mg} \mathrm{kg}^{-1}$ for fludioxonil. Excellent linearity with the coefficients of determination $\left(R^{2}>0.99\right)$ was achieved for the studied pesticides when using matrix-matched standards.

Measurement uncertainty of the method was estimated based on the "top-down" approach by using the recovery and precision data obtained in the validation study [22]. The expanded uncertainty was calculated individually for each pesticide as twice the value of the uncertainty $(k=2$, confidence level $95 \%$ ), and it ranged from 8 to $35 \%$ ( $22 \%$ on average), which was distinctively less than a maximum default value of $\pm 50 \%$ recommended by the European Union guidelines SANCO/12495/2011 (http://ec. europa.eu/food/plant/plant_protection_products/guidance_ documents/docs/qualcontrol_en.pdf).

\section{Field trials}

The post-harvest treatment of the apple fruits (e.g. dipping) against the storage diseases of fungal origin is not allowed in Poland. In order to keep fruit quality and to provide effective protection against storage diseases, 7-14 days before harvest (pre-harvest interval PHI), growers spray apples that are still on the trees with fungicides, to control 
Table 1 Method performance characteristics: limit of quantification (LOQ), linearity parameters, recovery, relative standard deviation (RSD) and expanded uncertainty values $(\mathrm{U})$ of fungicide analysis, in apples

\begin{tabular}{|c|c|c|c|c|c|c|}
\hline Pesticides & LOQ $\left(\mathrm{mg} \mathrm{kg}^{-1}\right)$ & Linearity range $\left(\mathrm{mg} \mathrm{kg}^{-1}\right)$ & $\mathrm{R}^{2}$ & Spiking level $\left(\mathrm{mg} \mathrm{kg}^{-1}\right)$ & Recovery \pm RSD $(\%)$ & $\mathrm{U}(\%)(k=2)$ \\
\hline Boscalid & 0.01 & $0.008-0.211$ & 0.999 & $\begin{array}{l}0.011 \\
0.211\end{array}$ & $\begin{array}{l}86.5 \pm 2.3 \\
91.7 \pm 0.9\end{array}$ & 10 \\
\hline Captan & 0.01 & $0.008-0.210$ & 0.997 & $\begin{array}{l}0.011 \\
0.210\end{array}$ & $\begin{aligned} 94.1 & \pm 15.1 \\
119.1 & \pm 7.3\end{aligned}$ & 35 \\
\hline Cyprodinil & 0.01 & $0.011-0.269$ & 0.999 & $\begin{array}{l}0.013 \\
0.269\end{array}$ & $\begin{array}{l}95.5 \pm 3.4 \\
94.8 \pm 2.8\end{array}$ & 10 \\
\hline Fludioxonil & 0.02 & $0.018-0.454$ & 0.995 & $\begin{array}{l}0.023 \\
0.454\end{array}$ & $\begin{array}{l}80.0 \pm 14.1 \\
71.1 \pm 3.3\end{array}$ & 35 \\
\hline Piraclostrobin & 0.01 & $0.008-0.201$ & 0.998 & $\begin{array}{l}0.010 \\
0.201\end{array}$ & $\begin{array}{l}118.2 \pm 13.7 \\
119.7 \pm 7.7\end{array}$ & 35 \\
\hline Trifloxystrobin & 0.01 & $0.007-0.171$ & 0.999 & $\begin{array}{l}0.009 \\
0.171\end{array}$ & $\begin{array}{l}98.1 \pm 2.8 \\
93.0 \pm 1.8\end{array}$ & 8 \\
\hline
\end{tabular}

pathogens responsible for developing these diseases. Because these treatments are performed in the orchard as the last ones before harvest, they generate the highest possible residue levels of the applied active ingredients (AIs).

To determine the overall relationship between application rate of the $\mathrm{AI}$ of plant protection product and its residue level in mature apples, six field trials were carried out on four varieties of dessert apples (Elise, Gloster, Golden Delicious and Lobo) using five plant protection products (Bellis $38 \mathrm{WG}$, Captan $80 \mathrm{WG}$, Merpan $80 \mathrm{WG}$, Switch $62.5 \mathrm{WG}$ and Zato $50 \mathrm{WG}$ ) containing a total six different AIs (Table 2). The studied AIs were: captan, pyraclostrobin, trifloxystrobin, boscalid, cyprodinil and fludioksonil, belonging to four different chemical groups.

Captan (trials 3 and 4) is a non-systemic phthalimide fungicide which is used to control many fungal diseases of fruit, mainly in apple production. Captan (Captan $80 \mathrm{WG}$, Merpan $80 \mathrm{WG}$ ) has a protective activity, and the main product of its degradation is tetrahydrofthalimid (THPI), which was also detected in some apples intended for manufacturing baby foods (unpublished data) and during apple processing [1]. Folpet (Folpan $80 \mathrm{WG)}$ ) is a chemical analogue of captan, and it is also registered for use in apple orchards in Poland. Similarly to captan, it undergoes decomposition to a phthalimide degradation product [5].

In trials 2, 5 and 6, pyraclostrobin and trifloxystrobin were used. Both compounds belong to the strobilurin group. They have systemic and protective activity [15]. In Poland, formulations containing these substances are often used. Compared with captan or folpet, these substances protect the fruit at lower doses not exceeding $100 \mathrm{~g} \mathrm{ha}^{-1}$. Another studied fungicides were: boscalid (an anilide fungicide of systemic action), cyprodinil (an anilinopyrimidine fungicide of systemic action) and fludioxonil (a phenylpyrrole fungicide) [7]. These three fungicides are effective at doses that can be classified as medium (200 $\left.\mathrm{g} \mathrm{ha}^{-1}\right)$.

All the fungicides used in the field trials were applied in accordance with the label recommendations, and their application rates covered a wide range of doses $(D)$, depending on the active ingredient. The lowest dose was used in the case of strobilurin fungicides

Table 2 Data on supervised field trials and the average residue levels of active ingredients, just after application of the plant protection product

\begin{tabular}{lllllll}
\hline $\begin{array}{l}\text { Trial } \\
\text { nos. }\end{array}$ & $\begin{array}{l}\text { Apple } \\
\text { variety }\end{array}$ & $\begin{array}{l}\text { Fungicide } \\
\text { formulation (WG) }\end{array}$ & $\begin{array}{l}\text { Application rate of product } \\
\left(\mathrm{kg} \mathrm{or} \mathrm{L} \mathrm{ha}{ }^{-1}\right)\end{array}$ & $\begin{array}{l}\text { Active } \\
\text { ingredient (AI) }\end{array}$ & $\begin{array}{l}\text { Application rate of AI } \\
\left(\mathrm{kg} \mathrm{ha}^{-1}\right)\end{array}$ & $\begin{array}{l}\text { Average residue level } \\
\left(\mathrm{mg} \mathrm{kg}^{-1}\right)\end{array}$ \\
\hline 1 & Gloster & Switch 62.5 & 0.800 & Cyprodinil & 0.300 & $0.236 \pm 0.064$ \\
& & & Fludioxonil & 0.200 & $0.294 \pm 0.039$ \\
2 & Lobo & Zato 50 & 0.200 & Trifloxystrobin & 0.100 & $0.126 \pm 0.016$ \\
3 & Gloster & Merpan 80 & 1.900 & Captan & 1.520 & $2.090 \pm 0.545$ \\
4 & Elise & Captan 80 & 1.900 & Captan & 1.520 & $1.765 \pm 0.440$ \\
5 & Golden & Bellis 38 & 0.800 & Boscalid & 0.202 & $0.236 \pm 0.128$ \\
& Delicious & & & Pyraclostrobin & 0.102 & $0.092 \pm 0.051$ \\
6 & Gloster & Zato 50 & 0.150 & Trifloxystrobin & 0.075 & $0.106 \pm 0.031$ \\
\hline
\end{tabular}


$\left(0.075-0.102 \mathrm{~kg} \mathrm{ha}^{-1}\right)$, somewhat higher in the case of boscalid, cyprodinil and fludioxonil (0.200-0.300 kg ha $\left.{ }^{-1}\right)$, and the highest for captan $\left(1.52 \mathrm{~kg} \mathrm{ha}^{-1}\right)$.

\section{Application rates versus residue levels of fungicides}

Data on field trials and residue levels of boscalid, captan, cyprodinil, fludioxonil, pyraclostrobin and trifloxystrobin which have been found in mature apples in the following days after their applications are summarized in Table 2. In estimation of the obtained results, we assumed that the relationship between the dose of any AI of plant protection product and its average residue level in mature apples may be well approximated by a linear function, and thus, based on obtained results, such correlation had been expressed by the following equation (see also Fig. 1):

$R_{0}=1.2593 \times D ;$

Coefficient of determination $r^{2}=0.9846$,

where $R_{0}$ is the average residue level $\left(\mathrm{mg} \mathrm{kg}^{-1}\right)$ of a given substance which may be found in mature apples just after its application at a $D$ dose $\left(\mathrm{kg} \mathrm{ha}^{-1}\right)$, and the numeric value of 1.2593 represents residue level of any substance if it is applied at a dose of $1 \mathrm{~kg} \mathrm{ha}^{-1}$.

As can be seen in Table 3, this mathematical formula makes possible the calculation of the average residue level of any fungicide now in use in the apple orchards, as well for each substance possessing fungicidal properties for the future introduction to the plant protection programs. Moreover, knowing the initial residue level $\left(R_{0}\right)$ of a given substance and constant rate $(k)$ of its exponential dissipation, determined independently, we may predict its concentration at any $t$-time, according to the general formula: $R_{t}=R_{0} \times \mathrm{e}^{-k t}[9]$ and then

$R_{t}=1.2593 \times D \times \mathrm{e}^{-k t}$.

The above formula, moreover, makes it possible to estimate residue level $\left(R_{t}=\mathrm{PHI}\right)$ of a given substance just

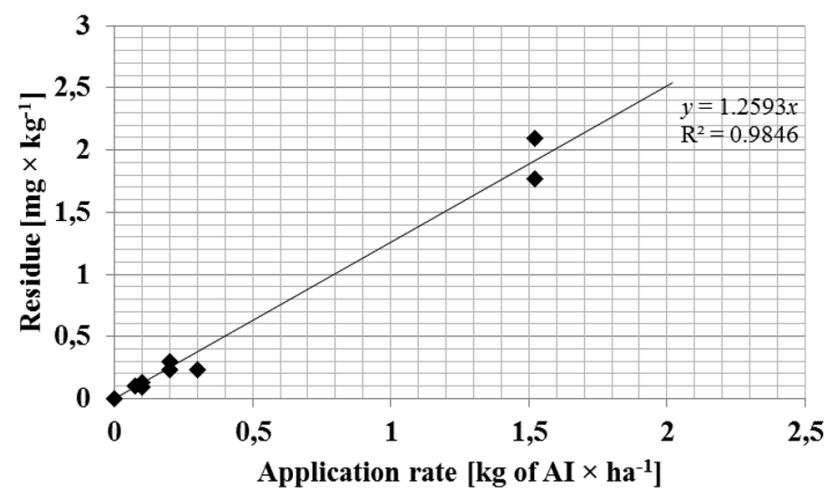

Fig. 1 Initial residue level ( $y$-axis) versus the application rate ( $x$-axis) of the studied fungicides after a fixed pre-harvest interval (PHI) and to compare it with the monitoring data, to ensure the correctness of the pesticide application in crop protection.

\section{Predicted residue levels of fungicides just after treatment versus their MRLs now in force}

The reduction of yield losses caused by pests and pathogenic fungi is the major challenge for agricultural production [13]. Ideally, pesticides should maintain the pest population at lower level than that causing economically unacceptable damage or loss, but without leaving residues in the edible parts of crops [10]. This is possible very rarely, and for this reason, legally, maximum residue levels (MRLs; "tolerances" in the USA) must be established for particular combination of pesticide and commodity. These MRLs are the upper permissible levels of pesticide residues and are set in order to ensure the lowest possible (!) consumer exposure according to the European Union legislation framework Regulation (EC) No 396/2005 (http://eurlex.europa.eu/LexUriServ/LexUriServ.do?uri=OJ:L:2005: 070:0001:0016:en:PDF).

Table 3 summarizes plant protection products recommended for control of diseases of fungal origin in apple orchards in Poland and their application rates along with MRLs currently in force in the European Union. As seen, the expected initial pesticide residue levels were all well below European MRLs, and therefore, they do not indicate any possibility of violation of regulatory limits. In general, our study indicates a significant discrepancy between MRLs and residue levels $\left(R_{0}\right)$ immediately after treatments as calculated on the basis of the established relationship. We found that good consistency between the two values occurs in the case of kresoxim-methyl (MRL $=0.2$ vs. $R_{0}=0.13 \mathrm{mg} \mathrm{kg}^{-1}$ ), captan and folpet (MRL $=3 \mathrm{vs}$. $R_{0}<3 \mathrm{mg} \mathrm{kg}^{-1}$ ) as well as for some triazoles, namely for fluquinconazole (MRL $=0.1$ vs. $R_{0}=0.09 \mathrm{mg} \mathrm{kg}^{-1}$ in periods of the high infection pressure) and propiconazole $\left(\mathrm{MRL}=0.15\right.$ vs., $R_{0}=0.09 \mathrm{mg} \mathrm{kg}^{-1}$ ). However, even for those few substances, after passing PHI period their residues will be also significantly below the MRLs.

The MRLs of other substances belonging to the triazole group (tebuconazole, myclobutanil, difenoconazole, triadimenol, fenbuconazole, tetraconazole), strobilurines (pyraclostrobin and trifloxystrobin), anilinopyrimidines (cyprodinil and pirimethanil) as well as the dodine and dithianon seem to be overestimated from 2 to 13 times. Furthermore, the discrepancies between MRLs and the final residue levels would be even greater, when taking into account their actual declines during the PHIs.

The proposed model of estimation of the residue level of fungicides in apples may facilitate not only setting MRLs for those fungicides and creation of their coherent system 
Table 3 Predicted initial residue levels $\left(R_{0}=1.2593 \times D\right)$ of AIs of fungicides against apple scab (Venturia inaequalis) in ripe apples, just after their application according to the label directions $(D-$ application rate and $R_{0}$-predicted initial residue level) in comparison with the MRLs now in force

\begin{tabular}{|c|c|c|c|c|c|}
\hline Chemical group fungicide & PHI (days) & $\mathrm{AI}$ & $D^{\mathrm{a}}\left(\mathrm{kg} \mathrm{ha}^{-1}\right)$ & $R_{0}^{\mathrm{a}}\left(\mathrm{mg} \mathrm{kg}^{-1}\right)$ & $\operatorname{MRL}\left(\mathrm{mg} \mathrm{kg}^{-1}\right)$ \\
\hline \multicolumn{6}{|l|}{ Anilinopyrimidines } \\
\hline Chorus $50 \mathrm{WG}$ & ND & Cyprodinil & 0.15 & 0.19 & 1 \\
\hline Mythos 300 SC & 14 & Pyrimethanil & $0.3(0.45)$ & $0.38(0.57)$ & 5 \\
\hline Vision $250 \mathrm{SC}$ & 30 & Pyrimethanil & $0.2(0.3)$ & $0.25(0.38)$ & 5 \\
\hline \multicolumn{6}{|l|}{ Quinones } \\
\hline Delan $700 \mathrm{WG}$ & 21 & Dithianon & $0.35(0.525)$ & $0.44(0.66)$ & 3 \\
\hline Tercel 16 WG & 35 & Dithianon & $0.24(0.3)$ & $0.30(0.38)$ & 3 \\
\hline Ventop $350 \mathrm{SC}$ & 14 & Dithianon & $0.35(0.525)$ & $0.44(0.66)$ & 3 \\
\hline \multicolumn{6}{|l|}{ Benzimidazoles } \\
\hline Topsin M 500 SC & 14 & Thiophanate-methyl & 0.75 & 0.94 & 0.5 \\
\hline \multicolumn{6}{|l|}{ Phthalimides } \\
\hline Captan $50 \mathrm{WP}$ & 7 & Captan & 1.5 & 1.89 & 3 \\
\hline Captan/Merpan 80 WG & 7 & Captan & $1.52(2.24)$ & $1.91(2.82)$ & 3 \\
\hline Kaptan Plus 71.5 WP & 7 & Captan & 1.4 & 1.76 & 3 \\
\hline Kaptan zawiesinowy 50 WP & 7 & Captan & 1.5 & 1.89 & 3 \\
\hline Folpan $80 \mathrm{WG}$ & 20 & Folpet & 2.4 & 3.02 & 3 \\
\hline Shavit F 72 & 20 & Folpet & $1.05(1.4)$ & $1.32(1.76)$ & 3 \\
\hline \multicolumn{6}{|l|}{ Guanidine derivatives } \\
\hline Carpene $65 \mathrm{WP}$ & 14 & Dodine & 0.975 & 1.23 & 5 \\
\hline Syllit 65 WP & 14 & Dodine & $0.65(1.46)$ & $0.82(1.84)$ & 5 \\
\hline \multicolumn{6}{|l|}{ Strobilurins } \\
\hline Ardent $500 \mathrm{SC}$ & 28 & Kresoxim-methyl & 0.1 & 0.13 & 0.2 \\
\hline Discus 500 WG & 28 & Kresoxim-methyl & 0.1 & 0.13 & 0.2 \\
\hline Signum $33 \mathrm{WG}$ & 14 & Pyraclostrobin & 0.054 & 0.06 & 0.3 \\
\hline Tercel $16 \mathrm{WG}$ & 35 & Pyraclostrobin & $0.08(0.1)$ & $0.10(0.13)$ & 0.3 \\
\hline Zato $50 \mathrm{WG}$ & 14 & Trifloxystrobin & 0.075 & 0.09 & 0.5 \\
\hline Bellis $38 \mathrm{WG}$ & 14 & Pyraclostrobin & 0.102 & 0.13 & 0.3 \\
\hline \multicolumn{6}{|l|}{ Anilides } \\
\hline Signum 33 WG & 14 & Boscalid & 0.214 & 0.27 & 2 \\
\hline Bellis $38 \mathrm{WG}$ & 14 & Boscalid & 0.202 & 0.25 & 2 \\
\hline \multicolumn{6}{|l|}{ Triazoles } \\
\hline Bumper $250 \mathrm{SC}$ & 14 & Propiconazole & 0.075 & 0.09 & 0.15 \\
\hline Capitan 400 EC & 14 & Flusilazole & 0.03 & 0.04 & 0.02 \\
\hline Difo $250 \mathrm{SC}$ & ND & Difenoconazole & 0.05 & 0.06 & 0.5 \\
\hline Domark 100 EC & ND & Tetraconazole & 0.06 & 0.08 & 0.3 \\
\hline Indar $5 \mathrm{EW}$ & 28 & Fenbuconazole & 0.035 & 0.04 & 0.4 \\
\hline Kaptan Plus 71.5 WP & 7 & Triadimenol & 0.03 & 0.04 & 0.2 \\
\hline Riza 250 EW & 14 & Tebuconazole & 0.125 & 0.16 & 1 \\
\hline Score $250 \mathrm{EC}$ & 14 & Difenoconazole & 0.05 & 0.06 & 0.5 \\
\hline Shavit 72 WG & 20 & Triadimenol & $0.03(0.04)$ & $0.04(0.05)$ & 0.2 \\
\hline Sparta $250 \mathrm{EW}$ & 14 & Tebuconazole & 0.125 & 0.16 & 1 \\
\hline Suplo 250 EC & 14 & Difenoconazole & 0.05 & 0.06 & 0.5 \\
\hline Systemic $125 \mathrm{SL}$ & 7 & Myclobutanil & $0.056(0.075)$ & $0.07(0.09)$ & 0.5 \\
\hline Talent $240 \mathrm{EC}$ & 14 & Myclobutanil & $0.06(0.072)$ & $0.08(0.09)$ & 0.5 \\
\hline Troja $250 \mathrm{EW}$ & 14 & Tebuconazole & 0.125 & 0.16 & 1 \\
\hline Vision $250 \mathrm{SC}$ & 30 & Fluquinconazole & $0.05(0.075)$ & $0.06(0.09)$ & 0.1 \\
\hline
\end{tabular}

${ }^{a}$ Application rates $(D)$, and thus predicted initial residue level $\left(R_{0}\right)$ added in brackets relate to periods of high infection pressures 
but also assessing the level of pesticide residues found in fruit and vegetables in the frame of National Monitoring Programs. Our results of the residue calculations in apples just after the treatment correspond well with the results of numerous data of pesticide residue monitoring. For example, in 2008, 141 of apple samples have been tested in Poland. Among the fungicides, the most frequently detected was captan (48.2\% samples), and the highest residue level was $1.9 \mathrm{mg} \mathrm{kg}^{-1}$ (the MRL value is $3 \mathrm{mg} \mathrm{kg}^{-1}$ ), while trifloxystrobin residue was found $0.02 \mathrm{mg} \mathrm{kg}^{-1}$ (the MRL value is $0.5 \mathrm{mg} \mathrm{kg}^{-1}$ ). The highest residue levels of cyprodinil, difenoconazole, dithiocarbamates, flusilazole, folpet and pyrimethanil were: $0.06,0.08,0.66,0.09,0.33$ and $0.35 \mathrm{mg} \mathrm{kg}^{-1}$, respectively, and all of them were well below the applicable MRLs [12]. These findings are also consistent with the results of other monitoring surveys conducted in Poland [11] and Czech Republic [20].

Pesticide MRLs provide an enforcement tool to ensure compliance with the registered pesticide labels and reassure that food products that move in commerce are safe for consumers. According to current registration practices, as described in Regulation (EC) No 1107/2009, pesticide MRLs are set based on data derived from supervised field trials (http://eur-lex.europa.eu/legal-content/EN/TXT/PDF/ ?uri=CELEX:32009R1107\&from=EN). On the other hand, according to Regulation (EC) No 396/2005 "MRLs should be set at the lowest achievable level consistent with good agricultural practice for each pesticide with a view to protecting vulnerable groups such as children and the unborn" (http://eur-lex.europa.eu/LexUriServ/LexUriServ. do?uri=OJ:L:2005:070:0001:0016:en:PDF). Also, bearing in mind that the European Union pesticide use policy, as reflected in Directive 2009/128/EC, is directed towards significant reductions in pesticide use (http://eur-lex. europa.eu/LexUriServ/LexUriServ.do?uri=OJ:L:2009:309: 0071:0086:en:PDF), we proposed that certain MRLs could be reconsidered and set at lower values based on pesticide residue monitoring data from surveys on crops produced under typical commercial conditions. It must be highlighted that applying the proposed approach neither mean a significant reduction in the number of initial field trials nor eliminate the need for zonal evaluation in the pesticide registration process but could be very useful for reviewing the existing MRLs, setting temporary MRLs and setting MRLs for pesticide residues in minor crops.

\section{Conclusions}

We proposed a simplified mathematical model showing the relationship between the application rate ( $D$ dose) of a given plant protection product (PPP) and the level residue of active ingredient (AI) of the substance in mature apples.
This model allows the assessment of MRL values for pesticides currently approved for the protection of apple orchards and prediction of the residue level of the substances whose application is currently under consideration, when their effective doses are known, as well as any other, which may be used in apple orchards in an undefined future. Using the proposed model, we could have assessed the current MRLs. Most of them, currently found in apple orchards protection programs in Poland, as it turned out, were fixed at too high levels. We have made a comparison between level of some pesticide residues found in the mature apples within the framework of National Monitoring Programs of residue surveys carried out in Poland and the Czech Republic, and the initial level of the residue of the same substances predicted by the model. This comparison clearly has shown that the MRLs currently in force in the EU countries require verification. In the creation of a coherent system MRL an equation $R_{t}=R_{0} \mathrm{e}^{-k t}$ may be helpful, especially $R_{t}=1.2593 \times D \times \mathrm{e}^{-k t}$, which takes into account the relationship between the application rate of the plant protection product and the residue level of an active ingredient in the mature apples.

Open Access This article is distributed under the terms of the Creative Commons Attribution 4.0 International License (http://crea tivecommons.org/licenses/by/4.0/), which permits unrestricted use, distribution, and reproduction in any medium, provided you give appropriate credit to the original author(s) and the source, provide a link to the Creative Commons license, and indicate if changes were made.

\section{References}

1. Alary J, Bescos D, Monge MC, Debrauwer L, Bories G (1995) Laboratory simulation of captan residues degradation during apple processing. Food Chem 54(2):205-211

2. Ambrus Á, Lantos J (2002) Evaluation of the studies on decline of pesticide residues. J Agric Food Chem 50(17):4846-4851

3. Ambrus Á (2000) Within and between field variability of residue data and sampling implication. Food Addit Contam 17(7):519-537

4. van Boxstael S, Habib I, Jacxsens L, De Vocht M, Baert L, Van De Perre E et al (2013) Food safety issues in fresh produce: bacterial pathogens, viruses and pesticide residues indicated as major concerns by stakeholders in the fresh produce chain. Food Control 32(1):190-197

5. Cabras P, Angioni A, Caboni P, Garau VL, Melis M, Pirisi FM et al (2000) Distribution of folpet on the grape surface after treatment. J Agric Food Chem 48(3):915-916

6. Drogué S, DeMaria F (2012) Pesticide residues and trade, the apple of discord? Food Policy 37(6):641-649

7. Gabriolotto C, Monchiero M, Negre M, Spadaro D, Gullino ML (2009) Effectiveness of control strategies against Botrytis cinerea in vineyard and evaluation of the residual fungicide concentration. J Environ Sci Health, Part B 44(4):389-396

8. MacLachlan DJ, Hamilton D (2010) Estimation methods for maximum residue limits for pesticides. Regul Toxicol Pharmacol 58(2):208-218 
9. Malhat F, Kamel E, Saber A, Hassan E, Youssef A, Almaz M et al (2013) Residues and dissipation of kresoxim methyl in apple under field condition. Food Chem 140(1-2):371-374

10. Mouron P, Heijne B, Naef A, Strassemeyer J, Hayer F, Avilla J et al (2012) Sustainability assessment of crop protection systems: sustainOS methodology and its application for apple orchards. Agric Syst 113:1-15

11. Nowacka A, Gnusowski B, Walorczyk S, Drożdżyński D, Raczkowski M, Hołodyńska A et al (2011) Pozostałości środków ochrony roślin w płodach rolnych (rok 2010). Prog Plant Prot 50(4): $1723-1738$

12. Nowacka A, Gnusowski B, Walorczyk S, Drożdżyński D, Wójcik A, Raczkowski M et al (2009) Pozostałości środków ochrony roślin w płodach rolnych (rok 2008). Prog Plant Prot 49(4):1903-1917

13. Popp J, Peto K, Nagy J (2013) Pesticide productivity and food security. A Rev Agron Sustain Dev 33:243-255

14. Renwick AG (2002) Pesticide residue analysis and its relationship to hazard characterization (ADI/ARfD) and intake estimations (NEDI/NESTI). Pest Manag Sci 58(10):1073-1082

15. Reuveni M (2002) Efficacy of trifloxystrobin (Flint), a new strobilurin fungicide, in controlling powdery mildews on apple, mango and nectarine, and rust on prune trees. Crop Prot 19(5):335-341

16. Reynolds SL, Fussel RJ, MacArthur R (2005) Investigation into validity of extrapolation in setting maximum residue levels for pesticides in crops of similar morphology. Food Addit Contam 22(1):31-38

17. Sadło S, Szpyrka E (2001) Behaviour of pyrimethanil residues on tomato plants. J Plant Prot Res 41(3):302-308

18. Sadło S (1998) Partition coefficient-its determination and significance in estimation of pesticide residue losses in the course of extraction procedure. J Plant Prot Res 38(2):179-184

19. Solecki R, Davies L, Dellarco V, Dewhurst I, van Raaij M, Tritscher A (2005) Guidance on setting of acute reference dose (ARfD) for pesticides. Food Chem Toxicol 43(11):1569-1593

20. Stěpán R, Tichá J, Hajšlová J, Kowalczuk T, Kocourek V (2005) Baby food production chain: pesticide residues in fresh apples and products. Food Addit Contam 22(12):1231-1242

21. Valverde-Garcia A, Gonzalez-Pradas E, Aguilera-des Real A (1993) Analysis of buprofezin residues in vegetables. Application to the degradation study on eggplant grown in a greenhouse. J Agric Food Chem 41(12):2319-2323

22. Walorczyk S, Drożdżyński D (2011) Development and validation of a routine multiresidue method for determining 140 pesticides in fruits and vegetables by gas chromatography/tandem quadrupole mass spectrometry. J AOAC Int 94(5):1625-1642

23. Wilson J, Otsuki T (2004) To spray or not to spray: pesticides, banana exports, and food safety. Food Policy 29(2):131-146

24. Winchester N, Rau M-L, Goetz C, Larue B, Otsuki T, Shutes K et al (2012) The impact of regulatory heterogeneity on agro-food trade. World Econ 35(8):973-993 